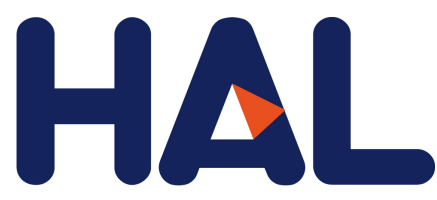

archives-ouvertes

\title{
What good's a text? Textuality, orality, and mathematical astronomy in early imperial China
}

Daniel Patrick Morgan

\section{To cite this version:}

Daniel Patrick Morgan. What good's a text? Textuality, orality, and mathematical astronomy in early imperial China. Archives internationales d'histoire des sciences, Académie internationale d'histoire des sciences, 2015, 65 (2), pp.549-572. $<$ http://www.brepolsonline.net/doi/abs/10.1484/J.ARIHS.5.112777?af=R

>. $<$ halshs-01362429v2>

\section{HAL Id: halshs-01362429 \\ https://halshs.archives-ouvertes.fr/halshs-01362429v2}

Submitted on 5 Oct 2016

HAL is a multi-disciplinary open access archive for the deposit and dissemination of scientific research documents, whether they are published or not. The documents may come from teaching and research institutions in France or abroad, or from public or private research centers.
L'archive ouverte pluridisciplinaire HAL, est destinée au dépôt et à la diffusion de documents scientifiques de niveau recherche, publiés ou non, émanant des établissements d'enseignement et de recherche français ou étrangers, des laboratoires publics ou privés.

\section{(ㅇ)(1) $\$$}

Distributed under a Creative Commons Attribution - NonCommercial - NoDerivatives $\mid 4.0$ 


\title{
What Good's a Text?
}

\author{
Textuality, Orality, and Mathematical Astronomy in Early Imperi- \\ al China
}

\author{
Daniel Patrick MORGAN \\ (ERC Project SAW, CNRS - Université Paris Diderot) ${ }^{*}$
}

\begin{abstract}
This paper examines a $226 \mathrm{CE}$ debate on $l i$ 曆 mathematical astronomy at the Cao-Wei (226-265) court as a case study in the role of orality and person-to-person exchange in the transmission of astronomical knowledge in early imperial China. The $l i$ - and mathematics-related manuscripts to have come down to us from the early imperial period often suffer from textual corruption, the form that this corruption takes being rooted in a culture of manuscript transmission by visual copying. Where numbers are involved, such corruption can significantly affect a text's readability, reliability, and utility, and it is hardly a surprise, I argue, that actors speak of learning $l i$ by any way but reading. In $226 \mathrm{CE}$, two men showed up to a debate with different versions of Liu Hong's 劉洪 (fl. 167-206 CE) Supernal Icon li (Qianxiang li 乾象曆), the one-the assistant director of the astronomical bureau - trying to best it, and the other-Liu Hong's disciple - trying to defend it. Reconstructing the tortuous route by which Liu Hong's astronomy made it into each man's hands via a transmission network spanning the Three Kingdoms, I argue that this debacle, and its conclusion, are to be expected from the mode of oral and written transmission particular to astronomy in this age.
\end{abstract}

\section{Introduction}

In 226 the fledgling Cao-Wei 曹魏 court (220-265) convened the brightest minds and greatest statesmen of a generation to deliberate upon a system of $l i$ 曆 mathematical astronomy authored by Han Yi 韓翊, the assistant director of the state astronomical office. It is difficult today to imagine a debate over US Naval Observatory time service policy drawing such a crowd, let alone its transcript earning a place in our imperial history, but these were different times. Let us think of this as a space race. Feckless and moribund for longer than living memory, the Han Empire (206 BCE - 220 CE) was no more; and in its place, through generations of treachery, alliance, and armed conflict, there arose three great powers-Cao-Wei, Sun-Wu 孫吳 (220-280), and Liu-Shu 劉蜀 (221-263) — the precarious balance of which was poised to devolve into total war. Our world, the 'subcelestial realm', cannot be held together by force alone, it was commonly understood, but by mandate - the mandate of Heaven, a totalistic political, natural, and theological approval witnessed, most im-

\footnotetext{
* The research leading to these results has received funding from the European Research Council under the European Union's Seventh Framework Programme (FP7/2007-2013) / ERC Grant agreement n. 269804. I would like to thank Martha Cecilia Bustamante for inviting me to participate in the current volume and Karine Chemla for her all her support and corrections as concerns the original paper.
} 
portantly, in the rapport maintained between celestial bodies and the body politic. ${ }^{1}$

And so it was that our fledgling court wove the story of its rise through an elaborate tapestry of prophecy, miracle, and augury. ${ }^{2}$ In their haste, however, they neglected the one thread that ties everything together: like the empire from which it had been inherited, the state $l i$ of 85 CE was, by 220, a faltering relic begging for reform; and in 222, amid Cao-Wei hesitation, the Sun-Wu court laid claim to Liu Hong's 劉洪 (fl. 167-206) cutting-edge Supernal Icon li (Qianxiang $l i$ 乾象曆). ${ }^{3}$ After several years of testing, Han Yi and his supporters in the Cao-Wei astronomical office were confident that they had the very sort of breakthrough needed to up the ante. On the day of the debate, however, Liu Hong's former pupil, Xu Yue 徐岳, produced from nowhere a set of eclipse data favouring his master four to one. At that:

翊於課難徐岳: 「乾象消息但可減, 不可加。加之無可說, 不 可用。」

[Han] Yi challenged Xu Yue over the test results: 'The Supernal Icon xiaoxi 消息 can only be subtracted, it cannot be added. There is no way to explain adding it. [This] is useless!'

岳云: 「本術自有消息, 受師法, 以消息為奇, 辭不能改, 故 列之正法消息。」

$[\mathrm{Xu}]$ Yue said, 'The original procedure itself has xiaoxi; I have received the master's method (shifa 師法), and it is the xiaoxi that make it astonishing. I am afraid that this cannot be changed, thus I have arranged here the proper method of xiaoxi.'

\section{翊術自疏。}

${ }^{1}$ On the Mandate of Heaven and its astronomical facets, see David W. Pankenier, Astrology and Cosmology in Early China: Conforming Earth to Heaven (Cambridge: Cambridge University Press, 2013), esp. pp. 193-258.

${ }^{2}$ On the legitimation project behind the abdication of the Han throne to the Cao-Wei, see Howard L. Goodman, Ts'ao P'i Transcendent: The Political Culture of Dynasty-Founding in China at the End of the Han (Seattle: Scripta Serica, 1998).

${ }^{3}$ Sanguo zhi 三國志 (Zhonghua shuju 中華書局 ed.), p. 47.1129. For a Western-language introduction to the subject of $l i$ mathematical astronomy and its practice in this period, see Yabuuti Kiyosi 藪內清, 'Astronomical Tables in China, from the Han to the T'ang Dynasties', in Chügoku chūsei kagaku gijutsushi no kenkyū 中國中世科學技術史の研究, ed. by Yabuuti Kiyosi (Tōkyō: Kadokawa shoten, 1963), pp.445-92; Christopher Cullen, Astronomy and Mathematics in Ancient China: The Zhou bi suan jing (Cambridge: Cambridge University Press, 1996), pp. 1-66; Jean-Claude Martzloff, Le calendrier chinois: structure et calculs, 104 av. JC-1644: indétermination céleste et réforme permanente: la construction chinoise officielle du temps quotidien discret à partir d'un temps mathématique caché, linéaire et continu (Paris: Champion, 2009), esp. pp. 1-279. On Liu Hong's Supernal Icon $l i$ specifically, see Christopher Cullen, 'The First Complete Chinese Theory of the Moon: The Innovations of Liu Hong c. A.D. 200', Journal for the History of Astronomy, 33 (2002), 21-39. 
[Han] Yi backed down. ${ }^{4}$

We do not know what xiaoxi is (neither, apparently, did Han Yi), ${ }^{5}$ but there is a lot we do know about Liu Hong, and that is thanks largely to Li Chunfeng 李淳風 (602-670). Praising his Supernal Icon $l i$ as 'a turn towards the fine \& tight relative to previous methods' 於前法轉 為精密 and 'the exemplar for the calculations of the subsequent age' 後代推步之師表, ${ }^{6} \mathrm{Li}$ devotes a full half of his history of $l i$ in the Book of Jin (648) to preserving its written form and documenting its authorship, transmission, reception, and imitation. ${ }^{7}$ It is thanks to $\mathrm{Li}$ Chunfeng that we have 'the' Supernal Icon $l i$; it is thanks to him also, in the previous quote, that we are reminded to ask if there might not be more than one.

The procedure text preserved in Li Chunfeng's history (Book of Jin, fasc. 17) clearly falls short of the bigger picture that he paints. A li procedure text, first of all, is a finished product - a polished chain of tables and algorithms designed to calculate 'tight' results - and, as such, it reveals nothing of the process by which it came about. In 226 we hear that Liu Hong had 'absorbed himself in inner contemplation for more than twenty years' 潛精內思二十餘載, but we know nothing of what this entailed beyond 'investigation' ( kao 考), 'awakening' ( $w u$ 悟), and 'invention' (zuo 作). ${ }^{8}$ A procedure text, more importantly, is apt to undergo accretion, abridgement, and modification over its public and private lifespans. Our Supernal Icon li bears the date 'Jian'an 11, bingxu.23' 建安十一年丙戍 (206), ${ }^{9}$ when we know Liu Hong to have memorialized a Supernal Icon li to the Han throne by 189. Our Supernal Icon $l i$ occupies less than a single fascicle of the Book of Jin, while contemporary bibliographies record editions in

\footnotetext{
${ }^{4}$ Jin shu 晉書 (Zhonghua shuju ed.), p. 17.500.

${ }^{5}$ Whatever it is, xiaoxi appears nowhere in received $l i$, and experts as early as Yixing 一行 (683-727) already complain that 'the technique had not been passed down' 術不傳 (Xin Tang shu 新唐書 [Zhonghua shuju ed.], p. 17B.622). Extrapolating from the eclipse predictions preserved in this debate, Chen Jiujin 陳久金 makes a compelling case that this xiaoxi represents a correction for solar inequality in Zhongguo gudai tianwenxuejia 中國古代天文學家 (Beijing: Zhongguo kexue jishu chubanshe, 2008), pp. 112-15.

${ }^{6}$ Jin shu, pp. 17.498, 503. For more on Li Chunfeng in his role in compiling the relevant Book of Jin and Sui monographs, see Monographs in Tang Official History: Perspectives from the Technical Treatises of the Book of Sui, ed. by Damien Chaussende and others (Dordrecht: Springer, forthcoming).

${ }^{7}$ On the life and work of Liu Hong, see Chen Meidong 陳美東, 'Liu Hong de shengping, tianwenxue chengjiu he sixiang’ 劉洪的生平、天文學成就和思想, Ziran kexue shi yanjiu 自然科學史研究, 5.2 (1986), 129-42. For a fuller account of Liu Hong and the events of the 226 debate, see Daniel P. Morgan, Astral Sciences in Early Imperial China: Observation, Sagehood and the Individual (Cambridge: Cambridge University Press, forthcoming), ch. 2 and 5.

${ }^{8}$ Jin shu, pp. 17.500, 499.

${ }^{9}$ Cited in Jin shu, p. 17.504.
} 
(only) three and five. ${ }^{10}$ Our Supernal Icon $l i$ is simply $l i$, but Wang Fan's 王蕃 (228-266) Supernal Icon $l i$ is cited as an authority on 'heavenly patterns' (tianwen 天文) instrument-making and cosmology. ${ }^{11}$ Our Supernal Icon $l i$, more importantly, does not have xiaoxi, however 'astonishing' it may have proven in 226.

The written word can be problematic; and if Sanskritist has taught us anything it is that we should expect astronomical writings to have been produced, circulated, taught, and discussed in a manuscript age within a continuum of memory, speech, and song. ${ }^{12}$ All that's left of this world is its objects and written record, of course, but therein lie traces of this continuum. Debate transcripts like those cited above offer us rich grounds for exploring the oral culture of the astral sciences, as Christopher Cullen's work on the Eastern Han (25-220) has recently brought to our attention. ${ }^{13}$ Debate, however, is invariably at the end - the public policy end - of practice, and we shall focus here instead on what can be said for the education, research, and transmission practices leading up to such debates. To place the events surrounding 226 in the broader context of contemporary textual culture, we will begin with manuscripts. The nature of the corpora available to us will take us several centuries prior to the Supernal Icon $l i$, and away, importantly, from the polished, printed sources passed down through centuries of selection, redaction, and reprinting. As realia once operative in very cultures of technical practice that interest us, manuscripts stand to reveal important features of contemporary textual transmission, and what they reveal, I show, is visual copying and a liability to a host of mistakes and interventions particular thereto. With a clearer sense of the limits potentially imposed by the written word at this time, we will then return to the third century to consider what place astronomers gave it in education, argumentation, and tex-

${ }^{10}$ Sui shu 隋書 (Zhonghua shuju ed.), p. 34.1022, records a 3-fascicle Supernal Icon $l i$ as part of the Sui 隋 (581-618) imperial holdings; in Liang 梁 (502-557) holdings, it cites a 5-fascicle edition 'with commentary by Han Chief Commandant of the Kuaiji Eastern Regiment Liu Hong, et al.’ 漢會稽都尉劉洪等注, a 5fascicle edition with commentary by Kan Ze 闒澤 (below), and a 1-fascicle Qianxiang wuxing huanshu 乾象五星幻術 ('Supernal Icon Planetary Magic'). Xin Tang shu 新唐書 (Zhonghua shuju ed.), p. 59.1546, furthermore confirms that a 3fascicle edition would have been available to the Book of Jin's seventh-century compilers.

${ }^{11}$ Huntian xiang shuo 渾天象說, cited in Kaiyuan zhanjing 開元占經 (Siku quanshu ed.), p. 1.13a; cf. Song shu 宋書 (Zhonghua shuju ed.), pp. 23.673-74, and Jin shu, p. 11.285.

${ }^{12}$ See Agathe Keller's contribution to the present volume. On the 'heavenly patterns' (tianwen 天文) side of the astral sciences, there is of course the famous 'Butian ge' 步天歌 (Song for Pacing Heaven) for memorizing one's constellations, on which see Zhou Xiaolu 周曉陸, Butian ge yanjiu 步天歌研究 (Beijing: Zhongguo shudian, 2004).

${ }^{13}$ See Christopher Cullen, "Actors, Networks, and "Disturbing Spectacles" in Institutional Science: $2^{\text {nd }}$ Century Chinese Debates on Astronomy', Antiqvorvm Philosophia, 1 (2007), 237-67. 
tual transmission, the goal of which is to understand what went wrong for poor Han Yi in 226.

\section{Of Textual Transmission and Textual Corruption}

The closest thing to the Supernal Icon $l i$ with which the archaeological record has currently furnished us is probably the so-called $W u$ xing zhan 五星占 ('Planetary Omens'). The Wu xing zhan is an untitled silk manuscript in eight sections discovered in 1973 at Mawangdui 馬王堆 tomb 3 (sealed $168 \mathrm{BCE}$ ). As to contents, the $W u$ xing zhan's first five sections are devoted to planetary omens for the naked-eye planets; the latter three provide for Jupiter, Saturn, and Venus (the easy planets) mathematical models and 70-year visibility tables spanning 246-177 BCE computed more or less therefrom (Figure 1). ${ }^{14}$ As to context, the $W u$ xing zhan is one of several manuscripts (and manuscript-sections) devoted to the astral sciences in a larger tomb library covering history, political philosophy, divination, medicine, and macrobiotic hygiene, the library's owner, the young Marquis Li Xi 利狶 of Dai 䡉, appearing to have been an eclectic reader. $^{15}$

The $W u$ xing zhan itself is also rather eclectic. The manuscript combines elements from what in the received tradition are separate sciences: tianwen 'heavenly patterns' omenology and $l i$ mathematical astronomy. It fuses contradictory mathematical and hemerological models, ascribing the planets mean motions through the uneven lodges of heaven while, at once, having them hop like game pieces through a schematized divination board on earth. It is a Western Han (206 BCE - 9 CE) production, but it uses an 'origin' (yuan 元), or astronomical zero-point, of Qin Shihuang 秦始皇 1-I-1 (3 February 246 BCE?), first morning rising at Hall.L13 $5 d u$ (21h01m53s RA at epoch), which is clearly a relic of the previous empire's propaganda. ${ }^{16}$ Its greatest inconsistency, however, is that between the quality of the production and the quality of the text.

\footnotetext{
${ }^{14}$ For recent scholarship on the $W u$ xing zhan, see Takeda Tokimasa 武田時昌, 'Taihaku kōdo kō: Chūgoku kodai no wakusei undōron' 太白行度考一中国古代 の惑星運動論, Tōhō gakuhō 東方學報, 85 (2010), 1-44; Christopher Cullen, 'Wu Xing Zhan 五星占 “Prognostics of the Five Planets"', SCIAMVS, 12 (2011), 193249; Christopher Cullen, 'Understanding the Planets in Ancient China: Prediction and Divination in the Wu Xing Zhan', Early Science and Medicine, 16 (2011), 218 51.

${ }^{15}$ For the Mawangdui tomb 3 manuscript corpus, see Changsha Mawangdui Han mu jianbo jicheng 長沙馬王堆漢墓簡帛集成, ed. by Qiu Xigui 表錫圭 and others, 7 vols (Beijing: Zhonghua shuju, 2014). For the texts dealing specifically with 'astronomy', see Liu Lexian 劉樂賢, Mawangdui tianwen shu kaoshi 馬王堆 天文書考釋 (Guangzhou: Zhongshan daxue chubanshe, 2004).

${ }^{16}$ See Mo Zihan 墨子涵 (Daniel P. Morgan), 'Cong Zhoujiatai Rishu yu Mawangdui Wu xing zhan tan rishu yu Qin-Han tianwenxue de huxiang yingxiang' 從周家臺『日書』與馬王堆『五星占』談日書與秦漢天文學的互相影響,
} 
Figure 1: Wu xing zhan 五星占 dimensions and textual units

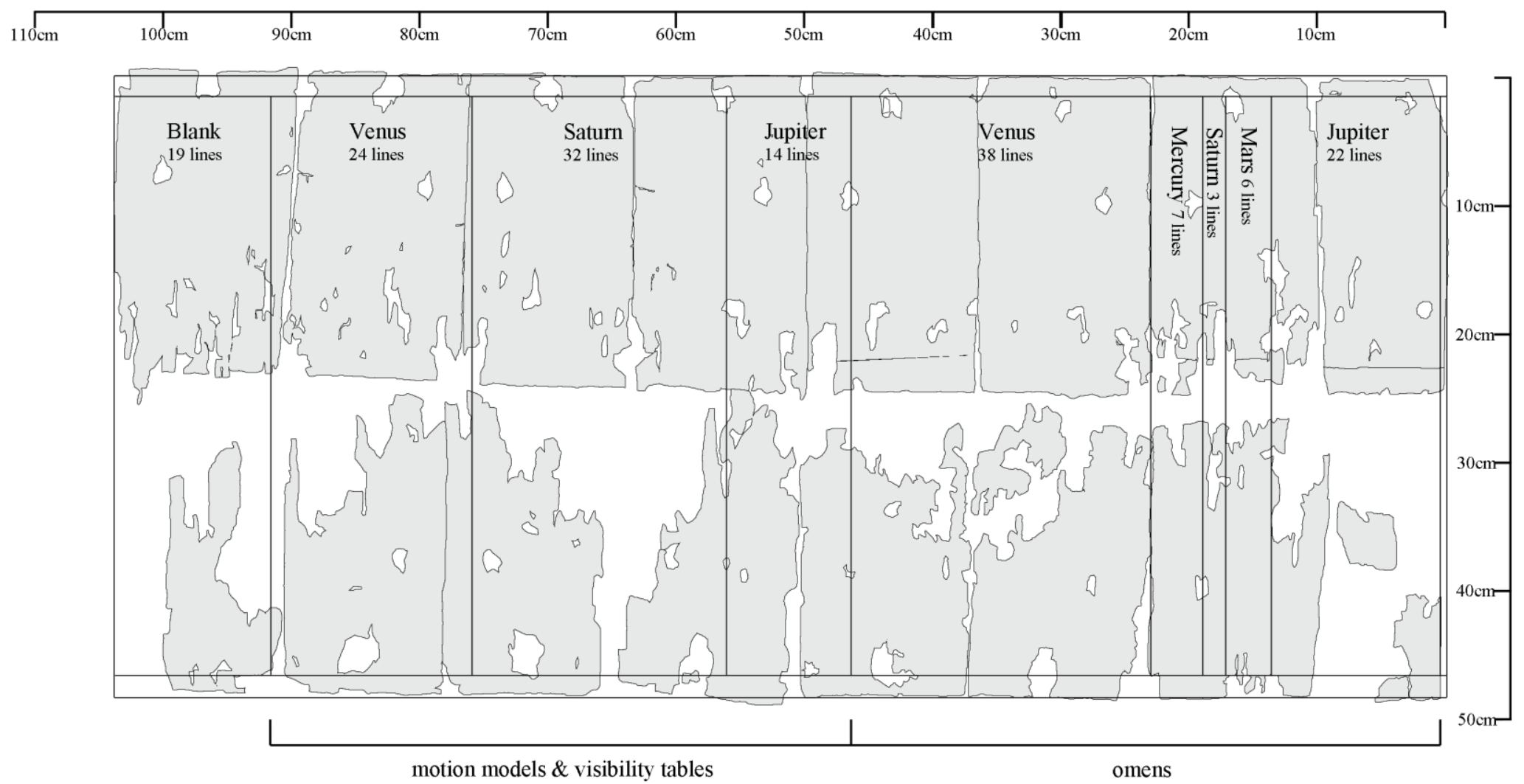


Figure 2: Wu xing zhan Saturn table calligraphy

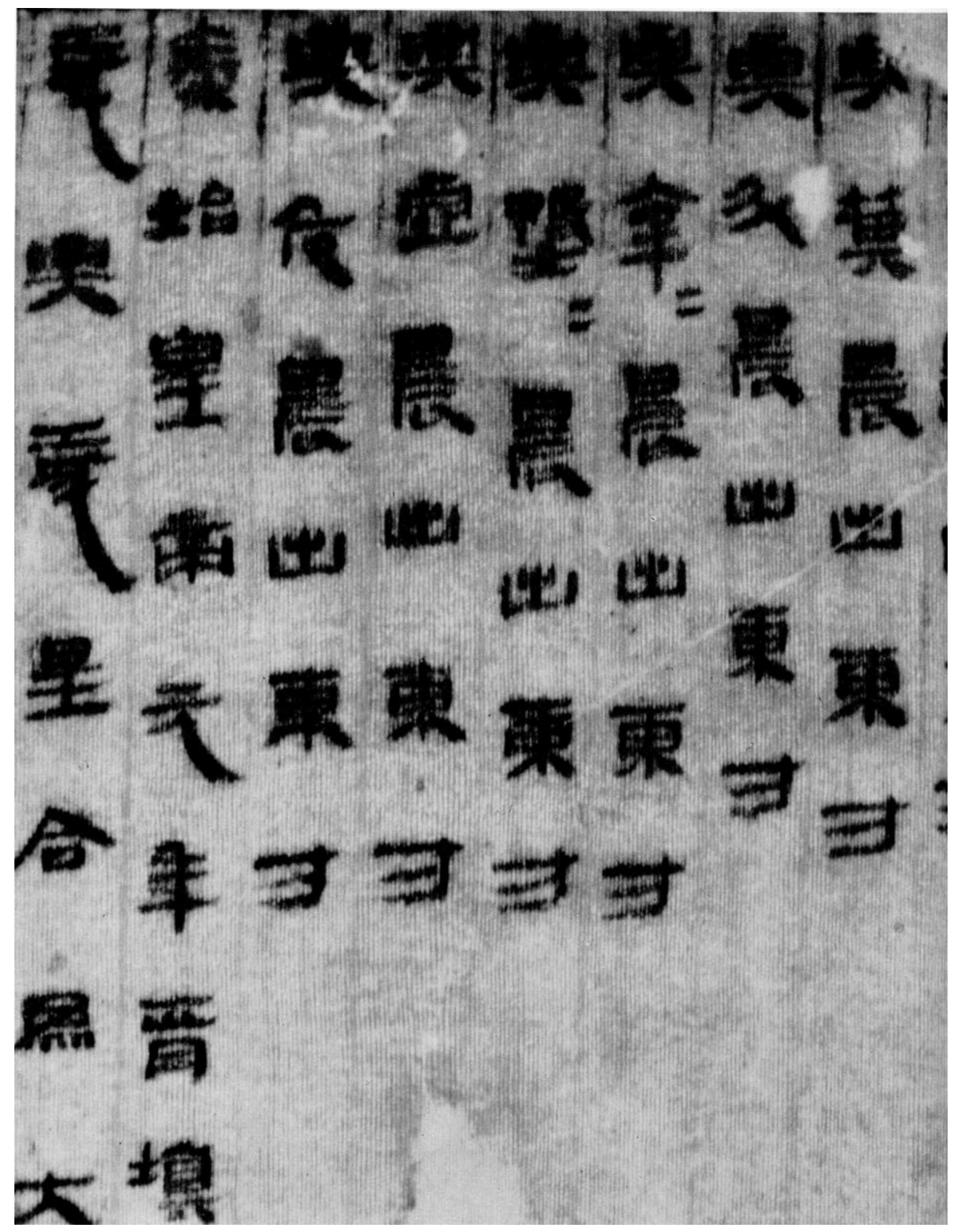

Source: Chen Songchang, Mawangdui boshu yishu, p. 185. 
The Wu xing zhan is written first of all on silk. As far as contemporary writing supports go, silk excelled its alternatives-bamboo and wood bookmats (see Figures $3 \& 4$ below) - in terms of quality, surface, portability, durability, contrast, and ink-absorption. Less amenable to correction, silk mostly lent itself to final editions of books first drafted on moveable, scrapable slips. ${ }^{17}$ The $W u$ xing zhan is written on a luxury support, but it is also written beautifully. Indeed, the Mawangdui corpus, as a whole, has proven as important for the history of calligraphy as it has for the history of ideas. The $W u$ xing zhan does not ooze with the archaism of the seal-inspired 'ancient clerical script' we see, for example, in Laozi 老子 manuscript A, but it is rendered in a standard and well-executed Han clerical script that is not without a certain modern elegance (see Figure 2). ${ }^{18}$ As beautiful as it is, however, the text is rife with mistakes. It is rife, specifically, with internal contradictions of a numerical nature that could only have been introduced by accident over the course of its transmission.

Let us consider three of these 'mistakes' occurring in the treatment of Venus in lines $123-46 .{ }^{19}$ First of all, the Venus table contradicts itself in repeating information from line to line. More specifically, in arranging the planet's four visibility phenomena ${ }^{20}$ in an eight-year cycle, the table repeats itself as concerns the month-date (I-XII) and zodiacal lodge (L01-28) of 'emergence' (chu 出), e.g.:

$$
\text { 十一月與箕晨出東方, 二百廿四日, 以六月與柳晨【入東】方。 }
$$

Jianbo 簡帛, 6 (2011), 113-37; Daniel P. Morgan, 'Mercury and the Case for Plural Planetary Traditions in Early Imperial China', in The Circulation of Astronomical Knowledge in the Ancient World, ed. by John M. Steele (Leiden: Brill, 2016), pp. 416-50; Daniel P. Morgan, 'The Planetary Visibility Tables in the SecondCentury BC Manuscript Wu xing zhan 五星占', East Asian Science, Technology, and Medicine, 43 (2016), $\mathrm{xx}-\mathrm{xx}$

${ }^{17}$ Tsien Tsuen-hsuin, Written on Bamboo \& Silk: The Beginnings of Chinese Books \& Inscriptions, 2d ed. (Chicago: University of Chicago Press, 2004), pp. 139-44.

${ }^{18}$ On the calligraphy of the Mawangdui manuscripts, see Mawangdui boshu yishu 馬王堆帛書藝術, ed. by Chen Songchang 陳松長 (Shanghai: Shanghai shudian, 1996), esp. pp. 1-6.

${ }^{19}$ To the examples given here one might add the omission of the key phrase 'emerges in the morning in the east with Hall.13' 與營室晨出東方 from the Jupiter model in line 89 or the contradiction between lines 1-4 and 77-88 concerning the months of Jupiter's first morning rising.

${ }^{20}$ Namely, (1) first morning rising, the planet's first morning appearance in the east after disappearing around inferior conjunction; (2) last morning rising, its last morning appearance before disappearing and going into superior conjunction; (3) first evening setting, its first evening appearance in the west after having moved past the sun; and (4) last evening setting, its last evening appearance before disappearing and going once again into inferior conjunction. For a description of the phenomena of the planets' synodic periods and early Chinese models thereof, see Michel Teboul, Les premières théories planétaires chinoises (Paris: Collège de France, 1983). 
Emerges in the east in the morning with Basket.L07 $(\gamma, \delta, \varepsilon, \eta$ Sgr) in month XI, 224 days, [enters in the east] in the morning with Willow.L24 $_{\text {( }} \delta-\theta$ Hya) in month VI (line 135).

浸行百廿日, 以九月心夕出西方, 取九十四下。

Travels submerged for 120 days, emerges in the west in the evening with Heart.L05 $(\sigma, \alpha, \tau$ Sco) in month IX, take 94 from below (line 136).

以九月心夕出西方, 二百廿四日, 以五月與東井入西方。

Emerges in the west in the evening with Heart.L05 in month IX, 224 days, enters in the west in the evening with Well. .22 $_{2}(\mathrm{Gem})$ in month V (line 137).

伏十六日九十六分, 以九月與與鬼晨出東方。

Hidden for 16 days and 96 parts of a day, emerges in the east in the morning with Cartborne Devils.L23 $(\theta, \eta, \gamma, \delta$ Cnc) in month IX (line 138).

以六月與舆鬼晨出東方, 二百廿四日, 以正月與西辟（壁）入 東方, 余五。

Emerges in the east in the morning with Cartborne Devils. .L23 $_{\text {in }}$ month VI, 240 days, month I, enters in the east in the morning with

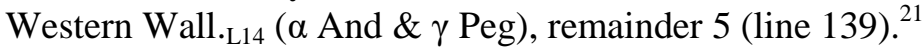

The latter two month-dates contradict one another- 'month IX' vs. 'month VI' - and this happens once again, earlier, in lines 128 and 129, between 'entering' ( $r u$ 入) in 'month IX' vs 'month VIII'.

The next two mistakes are self-evident only with respect to the principles governing early $x i n g d u$ 行度 ' $d u$ travelled' planetary models. These are: (1) symmetry (from conjunction) and (2) that visibility occurs at a fixed distance from the sun. For the inferior planets the consequence of these principles is furthermore that (3) the number of $d u$ 度 travelled over the course of both a synodic period and a period of morning/evening visibility must equal the number of days elapsed

\footnotetext{
${ }^{21}$ Cf. Cullen, 'Prognostics of the Five Planets', 244-45.

${ }^{22}$ Notes that there are additional problems with the month-dates in that the duration of planetary grades ('224 days', ' 120 days', etc.) correspond imperfectly with the respective difference in month-dates, be the latter understood as civil or solar months; see Yabuuti Kiyosi 藪內清, 'Baōtai san go bo shutsudo no Gosei sen ni tsuite' 馬王堆三號墓出土の「五星占」について, in Tōhōgaku ronshū: Ono Katsutoshi Hakushi shōju kinen 東方學論集: 小野勝年博士頌壽記念, ed. by Ono Katsutoshi 小野勝年 (Kyōto: Ryūkoku daigaku tōyō shigaku kenkyūkai, 1982), pp. 1-12 (p. 6); Cullen, 'Understanding the Planets in Ancient China', 247-48; Morgan, 'The Planetary Visibility Tables in the Second-Century BC Manuscript Wu xing zhan'.
} 
over the same period. ${ }^{23}$ The $W u$ xing zhan Venus model, as written, violates these principles:

\begin{abstract}
秦始皇帝元年正月, 大白出東方, 【日】行百廿分, 百日。行 益【疾, 日行一度, 六】十日。行有 (又) 益疾, 日行一度百 八十七半 [分] 以從日, 六十四日而復逻日, 晨入東方, 凡二百 廿四日。浸行百廿日, 夕出西方。太白出西【方, 日行一度百 八十七半分, 百日】。行益徐, 日行一度以侍 (待) 之, 六十 日。行有 (又) 益徐, 日行冊分, 六十四日而入西方, 凡二百 廿四日。伏十六日九十六分。【太白一復】爲日五【百八十四 日九十六分日。凡出入東方各五, 復】與營室晨出東方, 爲八 歲。

In Emperor Qin Shihuang 1-I, Great White (Venus) emerges in the east, traveling 120 parts (i.e. $1 / 240 \mathrm{du}$ ) [per day], 100 days. Movement increases in [speed: travels $1 d u$ per day, 6]0 days. Movement again increases in speed: travels $1 d u$ and 187 and a half [parts] per day following the Sun, 64 days, then catches up again with the Sun and enters in the morning in the east. This comes to a total of 224 days. It travels submerged for 120 days, and then emerges in the west. Great White emerges in the west, [traveling $1 d u$ and 187 and a half parts per day, 100 days.] Movement slows: travels $1 d u$ per day waiting for it (the Sun), 60 days. Movement again slows: travels 40 (sic) parts per day, 64 (sic) days, and then enters in the west. This comes to a total of 224 days. It hides for 16 days and 96 parts. [One return of Great White] takes 5[84 days and 96 parts of days. In total it emerges and enters in the east and west each five times, then again] emerges in the morning with Hall. ${ }_{\mathrm{L} 13}(\alpha, \beta, \gamma, \delta$ Peg) in the east, constituting 8 years (lines $143-46){ }^{24}$
\end{abstract}

Here, grade 7 gives a speed of 40/240 $d u$ per day rather than 120/240, as we would expect. In addition, though their ' $d u$ per day' are inverted between grades 1-3 and 5-7, their duration in 'days' are not. This violates principles (1) and (3), the result of which is that the $d u$ travelled over grades 5-7 that do not equal the number of days elapsed, thus violating principle (2). We can be certain that these are indeed

\footnotetext{
${ }^{23}$ The $d u$ ('measure/crossing') is a linear measure of the circumference of a great circle whereby one $d u$ equals the distance travelled by the mean sun in one day and the 'circuit of heaven' thus equals the length in days of the 'solar' (tropical + sidereal) year, i.e. $360^{\circ} \approx 3651 / 4 d u$. Because the inferior planet 'emerges' and 'enters' at the same distance from the sun (principle 2), the two necessarily travel the same distance over the course of a synodic period or a period of morning/evening visibility (whereby the planet returns to the same position vis-à-vis the sun); and given that the (mean) sun travels $1 d u$ per day, that distance, in $d u$, equals the time elapsed in days. For an explanation of these principles, see Teboul, Les premières théories planétaires chinoises, pp. 51-79.

${ }^{24}$ Note that editors are able to confidently reconstruct these planetary models where they are damaged based on the formulaic nature of their language, textual parallels, the measured size of missing silk, and assumptions of internal and intertextual coherence.
} 
Table 1: Wu xing zhan Venus model

\begin{tabular}{|c|c|c|c|}
\hline grade & $d u$ per day & days & $d u$ travelled \\
\hline Slow & $120 / 240$ & 100 & 50 \\
\hline Medium & & 60 & 60 \\
\hline Fast & $187^{1 / 2} / 240$ & 64 & 114 \\
\hline SUBTOTAL & & 224 & 224 \\
\hline Submerged & & 120 & $120+2 s$ \\
\hline Fast & $1871 / 2 / 240$ & 100 & $178 \quad 30 / 240$ \\
\hline Medium & & 60 & 60 \\
\hline Slow & $40 / 240$ & 64 & $10160 / 240$ \\
\hline 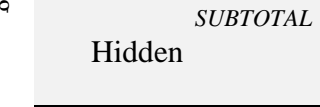 & & $\begin{array}{r}224 \\
16 \\
\quad 96 / 240\end{array}$ & $\begin{array}{c}248 \quad 190 / 240 \\
1696 / 240- \\
2 s\end{array}$ \\
\hline TOTAL & & $58496 / 240$ & $\begin{array}{ll}608 & 190 / 240\end{array}$ \\
\hline
\end{tabular}

Note: extant values are marked in grey; other values are restored/calculated on the basis of the three aforementioned principles of 'motion-degree models'. 
mistakes because the table computed from this model does obey these principles. $^{25}$

How did this happen? The fact that the errors of the model have not entered into the table calculated therefrom, and that the model indeed follows the table, suggests that the Mawangdui manuscript is not a working paper but an imperfect copy of an earlier text. As to the method of copying, the confusion of 'month IX'

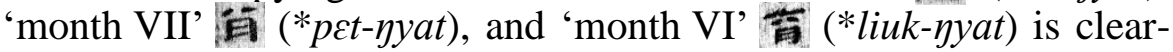
ly graphic (rather than phonetic) in nature. The same can probably be said for ' 120 ' 画 $\mathrm{(*pak-ńip)} \mathrm{and} \mathrm{'40'} \mathrm{tos} \mathrm{(*sip),} \mathrm{given} \mathrm{their} \mathrm{pho-}$ nological dissimilarity and the absence of the number 40 anywhere in the surrounding text (to which the copyist's eyes may have skipped). ${ }^{26}$ The (failed) inversion of the day-durations of grades 5-7, on the other hand, would seem to be the product of conscious scribal intervention by someone with a weak understanding of what he/she was copying, i.e. 'correcting' the days to match grades 1-3 or the descending order of " $d u$ per day" in grades 5-7. This, like the other mistakes, is clearly related to visual copying.

The Wu xing zhan is a 'luxury edition' of expository writing, but it reflects the same type of copy errors we find in one-use $l i$ documents on bamboo. Let us consider the bamboo calendars for Shihuang year 34 (213 BCE) from the Yuelu Academy collection and Zhoujiatai 周 家臺 tomb 30 (Figures $3 \& 4$ ). ${ }^{27}$ Exemplars of the zhiri 質日 'duty log' format, both manuscripts are divided into six registers, each of which begins with the sexagenary date of day 1 of the even months (beginning from month $\mathrm{X}$ ) and runs right to left through the subsequent days of this and the next (odd) month. Because the civil calendar alternates between 'big' and 'small' months of 30 and 29 days, with the occasional 'double big', zhiri leave blank spaces at the end of 'small' months (Figure 3, slip 29 reg. 1 and slip 59 reg. 2-6) to maintain the month-dates across registers. ${ }^{28}$ This way, column 1 is

\footnotetext{
${ }^{25}$ Mo Zihan, 'Cong Zhoujiatai Rishu yu Mawangdui Wu xing zhan tan rishu yu Qin-Han tianwenxue de huxiang yingxiang', pp. 125-26, 132-34.

${ }^{26}$ Phonetic reconstructions are according to Axel Schuessler's Late Han Chinese in ABC Etymological Dictionary of Old Chinese (Honolulu: University of Hawai'i Press, 2007). He Youqi 何幼琦 offers a somewhat similar explanation for this confusion in 'Shilun $W u$ xing zhan de shidai he neirong' 試論『五星占』的時 代和内容, Xueshu yanjiu 學術研究, 1979.1, 79-87.

${ }^{27}$ For transcriptions and photographs of these calendars, see Yuelu Qin jian 获 麓秦簡, ed. by Chen Songchang 陳松長, 4 vols (Shanghai: Shanghai cishu chubanshe, 2010-2015), vol. 1, pp. 10-18, 180-83; Guanju Qin-Han mu jiandu 關沮 秦漢墓簡牘, ed. by Hubei-sheng Jingzhou-shi Zhouliang yuqiao yizhi bowuguan 湖北省荊州市周梁玉橋遺址博物館 (Beijing: Zhonghua shuju, 2001), pp. 11-17, 93-99. On early imperial calendars, see Alain Arrault, 'Les premiers calendriers chinois du $\mathrm{II}^{\mathrm{e}}$ siècle avant notre ère au $\mathrm{X}^{\mathrm{e}}$ siècle', in Les Calendriers: Leurs enjeux dans l'espace et dans le temps: colloque de Cerisy, du $1^{\text {er }}$ au 8 juillet 2000, ed. by Jacques Le Goff, Jean Lefort, and Perrine Mane (Paris: Somogy, 2002), pp. 169-91.

${ }^{28}$ On the zhiri calendar-type, see Li Ling 李零, 'Shiri, rishu he yeshu一san zhong jianbo wenxian de qubie he dingming'視日、日書和葉書一三三種簡帛文 獻的區別和定名, Wenwu 文物, 2008.12, 73-80; Su Junlin 蘇俊林, 'Guanyu “zhiri”
} 
Figure 3: Yuelu Academy Sasi nian zhiri 卅四年質日 Shihuang 34 (213 BCE) calendar

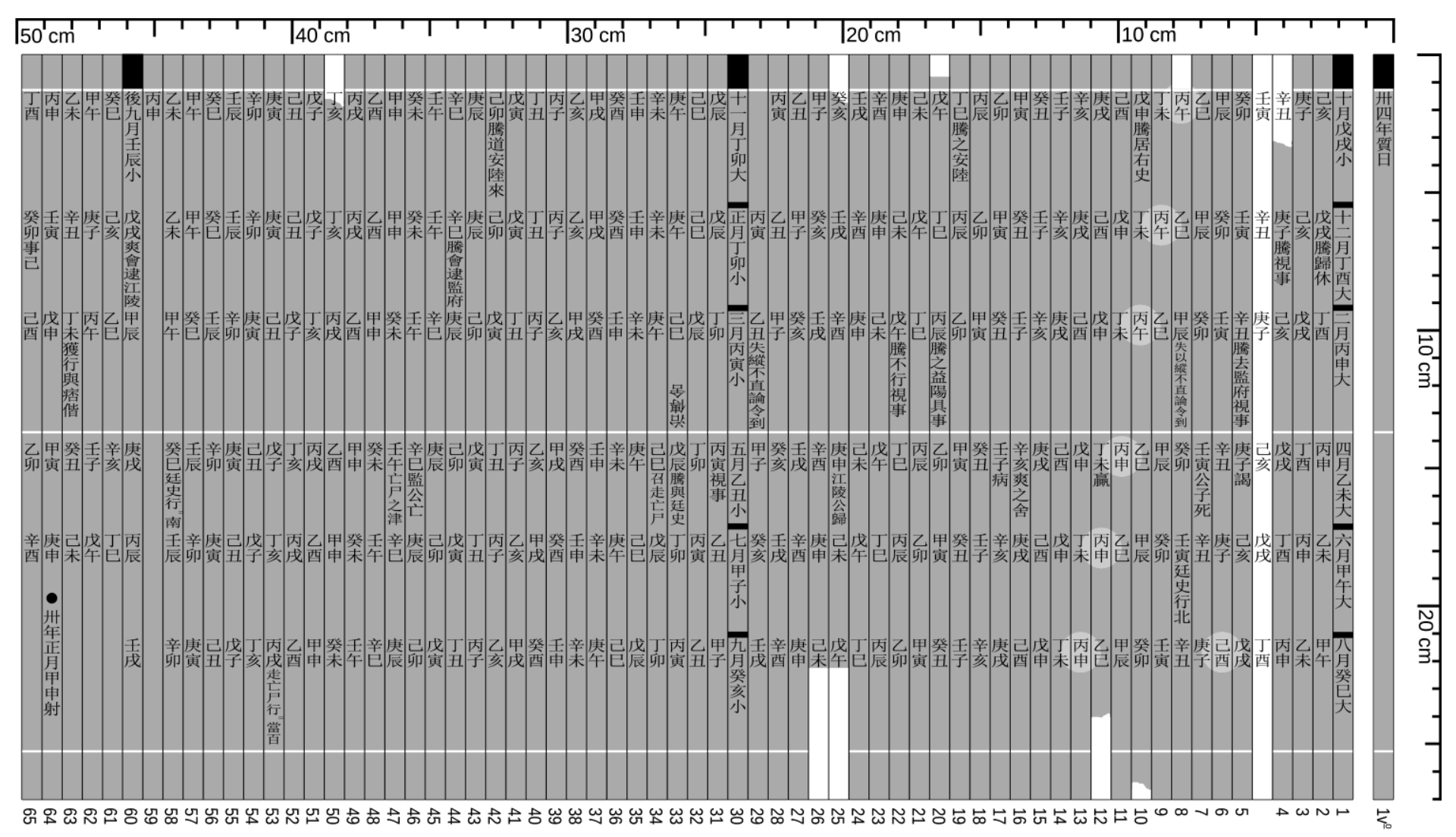


Figure 4: Zhoujiatai tomb 30 Shihuang 34 (213 BCE) calendar

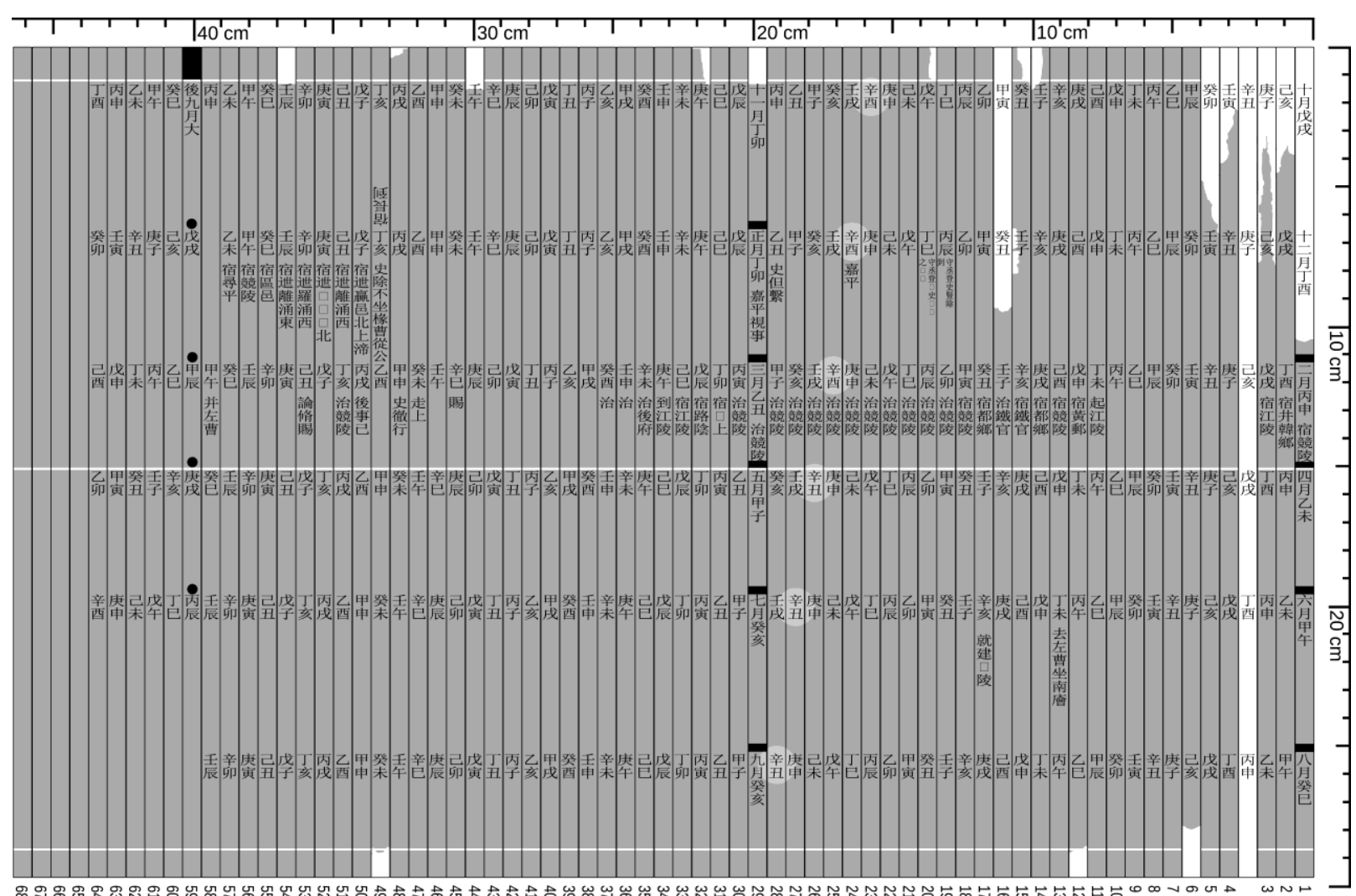

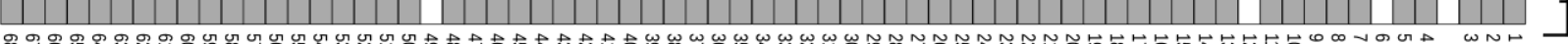


day 1 of each odd month and column 31 is day 1 of each even month. Barring a 'double-big' $(2 \times 30$ days $)$, each register contains fifty-nine days, which causes the sexagenary series to repeat one place to the left in each subsequent register.

The discovery of the Yuelu version has confirmed suspicions that the Zhoujiatai calendar is corrupt. The problem, comparison reveals, is that the latter omits the blank at the end of 'small' month X (Figure 4, reg. 1, slips 1-28) leaving no room for the last day of 'big' months XII, II, IV, VI, or VIII in subsequent registers. Aware of his mistake, the copyist skips the last day of month XII (bingyin.03) in register 2 but then lapses in registers 3-5, displacing months III, V, and VII one day forward; he does, however, correct himself in register 6. It is clear that this has happened because he has simply repeated the sexagenary dates of each register one place to the left of the one previous, running naturally 甲子 jiazi.01 $\rightarrow$ 乙丑 yichou.02 rather than 甲子 jiazi.01 $\rightarrow$ 丙寅 bingyin.03, for example, in the case of register 3 (slips 28-29). That this was indeed visual is confirmed by the fact that where the occasional mistaken sexagenary date occurs it is repeated in each subsequent register, as highlighted in Figures $3 \& 4 .^{29}$

Turning to suan 算 'mathematics', the bamboo manuscript Suan $s h u$ shu 等數書 ('Writings on Mathematical Procedures') from Zhangjiashan 張家山 tomb 247 (sealed $\geq 186$ BCE) tells a similar story. ${ }^{30}$ The majority of mistakes here too stem from copying rather than computation, and the majority of these involve either eyeskipping/omission or the confusion of orthographically similar characters. In other words, the sums work out, but they contain the occasional number or measuring unit that has been miswritten.

For example, the text regularly confuses the orthographically similar numbers $1-2=$, and $3 \equiv ; 1-$ and 7 th ; and 30 H4t and 40 tot. We even have a mistake in the context of dealing with a mistake:

jian de mingcheng yu xingzhi' 關於「質日」簡的名稱與性質, Hunan daxue xuebao (shehui kexue ban) 湖南大學學報（社會科學版）, 24.4 (2010), 17-22.

${ }^{29}$ Specifically, there is a mistake introduced in register 4 of both the Yuelu and Zhoujiatai Shihuang 34 calendars that is repeated (one place to the left) in reg. 5 and 6 (Yuelu reads 乙丑 yichou. . $_{02} \rightarrow$ 丙申 bingshen. . $_{33} \rightarrow$ 丁卯 dingmao. 04 ; Zhoujiatai reads 戊戊 wuxu. 35 己酉 jiyou.46 $\rightarrow$ 庚子 gengzi.37).

${ }^{30}$ For transcriptions and photographs of the Suan shu shu, see Zhangjiashan Han mu zhujian (ersiqi hao mu) 張家山漢墓竹簡（二四七號墓）, ed. by Zhangjiashan ersiqi hao Han mu zhujian zhengli xiaozu 張家山二四七號漢墓整理小組 (Beijing: Wenwu chubanshe, 2001), pp. 81-98, 247-72; cf. Kankan Sansūsho: Chūgoku saiko no sūgakusho 漢簡「算數書」: 中國最古の數學書, ed. by Chōkazan Kankan Sansūsho Kenkyūkai 張家山漢簡「算數書」研究會 (Kyōto: Hōyū shoten, 2006). For a translation and study in English, see Christopher Cullen, The Suàn Shù Shū 算數書 'Writings on Reckoning': A Translation of a Chinese Mathematical Collection of the Second Century BC, with Explanatory Commentary (Cambridge: Needham Research Institute, 2004). 
稅田。稅田甘四步 $\mathrm{L}$ 。八步一斗，租三斗。今誤券三斗一升。問： 幾何步一斗? 得曰: 七步卅七（一）分步廿卅而一斗 $\mathrm{L}$ 。术曰: 三斗一升者為法。十稅田。令如法一步。

Duty on a field. There is duty on a field of $24 b u . \quad$ $8 b u$ [produces] 1 dou, the tax is 3 dou. Now in error it is ticketed at 3 dou 1 sheng. Question: how many $b u$ give a dou [on that basis]? Result: 7 bu 23/37 (sic.) $b u$ [produce] 1 dou. L Method: make the 3 dou 1 sheng the divisor; 10-fold the field taxed; make it accommodate the divisor [to obtain] 1 bu (slips 68-69). ${ }^{31}$

The result here should clearly be $723 / 31 \mathrm{bu}$ as we are instructed to 'make the 3 dou 1 sheng (= 31 sheng) the divisor' (and $8 \times 30 / 31=$ $723 / 31$ ). The copyist has instead given us 37, the difference being an extra brushstroke.

Elsewhere, the manuscript tends also to confuse the orthographically similar capacity units dou $\mathbb{X}(\approx 2$ litres $)$ and sheng $\mathbb{\gtrless}$ $(1 / 10 \mathrm{dou}$, or $\approx 200 \mathrm{cc})$. For example:

米粟并。有米一石，粟一石。并提之。問：米粟當各取幾何？ 曰: 米主取一石二斗十六分升 (斗) 八, 粟主取七斗十六分斗 八。术曰: 直 (置) 米十斗, 六斗, 并以為法。以二石扁（遍） 乘所直（置）, 各自為實。六斗者, 粟之米數也。

Hulled and unhulled grain combined. There is 1 shi of hulled grain and 1 shi of unhulled grain. They are combined. Question: [the owners of] hulled and unhulled should each take how much? Reply: the owner of the hulled grain takes 1 shi 2 dou 8/16 sheng (sic.); the owner of the unhulled gain takes 7 dou 8/16 dou. Method: set out hulled grain $10 \mathrm{dou}$ and $6 \mathrm{dou}$, and combine to make the divisor; multiply all what has been set out by 2 shi so that each makes a dividend by itself. The 6 dou is the quantity of hulled corresponding to unhulled grain (slips 117-118). ${ }^{32}$

The owner of the hulled grain here should take 1 shi 2 dou 8/16 dou (12.5 dou) rather than 1 shi 2 dou 8/16 sheng (12.05 dou), of course, since $10 \times 20 / 16=12.5^{33}$

Stepping beyond the astral and mathematical sciences of tianwen, $l i$, and suan into $w u$ xing 五行 'five agents' hemerology, i.e. calendar divination, one sees further examples of these same phenomena. Take for instance the Mawangdui Xingde 刑德 ('Punishment \& Virtue'). The Xingde is a text in two parts: the first, a hemerology describing

${ }^{31}$ Trans. Cullen, Writings on Reckoning, p. 60.

32 Trans. ibid., p. 74.

${ }^{33}$ My presentation of the copy errors here derives from collaborative work with Karine Chemla on said manuscript, the first results of which can be found in Mo Zihan 墨子涵 (Daniel P. Morgan) and Lin Lina 林力娜 (Karine Chemla), 'Ye you lunzhe xiede: Zhangjiashan Han jian Suan shu shu xieshou yu bianxu chutan'也有 輪着寫的: 張家山漢簡『算數書』寫手與編序初探, Jianbo 簡帛, 12 (2016), 235-51. 
the seasonal, monthly, and daily circulation of the calendar spirits Punishment and Virtue through, essentially, a schematized game board correlating the sexagenary cycle, cardinal directions, and five agents (wood, fire, earth, metal, water), combinations of which determine the advantage/disadvantage of particular times and directions for political and military decisions; the second, a typical list of celestial omens. The Mawangdui tomb library contains three versions of the Xingde text (A, B, and $\mathrm{C}$ ) copied at different times, in different colours, and in different calligraphic styles. In lines 95 and 96 of Xingde $\mathrm{B}$, the copyist accidentally repeats a line as it appears exactly in Xingde A, his eye having clearly skipped to the wrong line as he copied visually from either Xingde A or a master copy identical in layout thereto. ${ }^{34}$ Marc Kalinowski notes that we also see evidence of scribal intervention:

Since most of the variants concern factual data such as the dates entered in the sexagenary grid and the description of the diurnal rotations of [Punishment and Virtue] for the eleventh year of Gaozu, there is every reason to think that copy B is an updating of copy A redacted some twenty years later by a specialist in calendrical techniques. Thus, the variants between the two copies do not necessarily indicate different textual traditions but rather seem to be the result of deliberate action by the copyist himself, even though he may well have used other versions of the text as he carried out his work. ${ }^{35}$

Kalinowski reaches a similar conclusion in his case study of the two daybooks (rishu 日書) recovered from the third-century BCE tomb 11 at Shuihudi 睡虎地 in Yunmeng 雲夢, Hubei. Like those proliferating third- and second-century BCE tombs, Kalinowski shows, daybooks A and B from Shuihudi are miscellanies formed of small independent units that copyists arranged more or less arbitrarily across each text according to complicated processes of selection. Editorial intervention did not stop there though, as we see in the case of 'Yi' 衣 (MS A, slips 113-22v), for example, where, after reproducing the text of the master copy, the copyist provides an emended version of the same hemerology. 'Il serait tout aussi absurde', Kalinowski concludes, 'de réduire l'activité des scripteurs de ce genre d'écrits à celle

\footnotetext{
${ }^{34}$ Chen Songchang 陳松長, 'Boshu Xingde yi ben shiwen jiaodu' 帛書『刑德』 乙本釋文校讀, in Hunan sheng bowuguan sishi zhounian jinian lunwenji 湖南省 博物館四十週年紀念論文集, ed. by Hunan-sheng bowuguan 湖南省博物館 (Changsha: Hunan jiaoyu chubanshe, 1996), pp. 83-87; cf. Marc Kalinowski, 'La production des manuscrits dans la Chine ancienne: Une approche codicologique de la bibliothèque funéraire de Mawangdui', Asiatische Studien/Études Asiatiques, 59.1 (2005), 131-68 (pp. 160-61).

35 'The Xingde 刑德 Texts from Mawangdui', trans. Phyllis Brooks, Early China, 23-24 (1998-1999), 125-202 (p. 128).
} 
de simples copistes que de leur concéder le privilège d'être les auteurs des textes qu'ils composaient.' 36

Mistakes, though they certainly occurred, are harder to identify in 'five-agents' manuscripts, which make is harder, in turn, to identify the writing practices by which they came about. Hemerology is an epistemic closed circuit that refers within a self-contained repertoire of symbols and mechanics and not, for example, to natural phenomena or basic mathematical operations that may be intersubjectively verified both within and beyond the culture and time in question. In other words, it's harder to know if a calendar spirit is moving in the 'right direction' than, say, a planet. Each of four extant versions of the 'Xuange' 玄戈 hemerology is different, for example, but the fact that they differ on the rules by which the fixed stars $\gamma$ and $\lambda$ Boötis cycle contrary to any astronomical sense through an array of divinatory emblems would seem to defy the question 'why'. ${ }^{37}$ Due to the distinctly personal nature of daybooks as 'copies de travail', what looks like 'corruption' might well just be innovation or abbreviation. The fact that Shuihudi daybook A occasionally cuts off a sentence where its copyist ran out of space, for example, may not have posed a problem for the savvy reader, especially if his was the hand that did the copying. ${ }^{38}$

In this section we have identified a variety of mistakes and copy errors common to early imperial manuscripts written on the astral sciences (tianwen and li), mathematics (suan), and 'five agents' calendar divination. Namely, these written sources bear witness to eyeskipping, visual confusion concerning numbers and their proper order, passive line-copying, and active intervention in the text. All of this points to direct visual copying as the mechanism behind their textual transmission; it also points to its limits. The Suan shu shu bears the signature of three 'checkers' (chou 隹誰), but even there there are mistakes, albeit nothing compared to the scribal errors and intervention muddling the Wu xing zhan. One would like to extend such copy error analysis to include technical genres like omenology, medicine, ritual, law, and administration, but the case of hemerological manuscripts reminds us of the challenges we face in this regard beyond $l i$

\footnotetext{
${ }^{36}$ Marc Kalinowski, 'Les livres des jours (rishu) des Qin et des Han: la logique éditoriale du recueil A de Shuihudi (217 avant notre ère)', T'oung Pao, 2d ser., 94.1 (2008), 1-48 (p. 24).

${ }^{37}$ On 'Xuange', Marc Kalinowski, 'Les traités de Shuihudi et l'hémérologie chinoise à la fin des Royaumes-Combattants', T'oung Pao, 2d ser., 72.4/5 (1986), 175-228 (pp. 219-20); Liu Lexian 劉樂賢, 'Shuihudi Qin jian rishu "Xuange pian” xin jie’ 睡虎地秦簡「玄戈篇」新解, Wenbo 文博, 1994.4, 74-76; cf. Liu Lexian, 'Yintai Han jian Rishu chutan' 印臺漢簡『日書』初探, Wenwu 文物, 2009.10, 92-96.

${ }^{38}$ On the personal nature of daybook-production, see especially Donald Harper, 'The Textual Form of Knowledge: Occult Miscellanies in Ancient and Medieval Chinese Manuscripts, Fourth Century B.C. to Tenth Century A.D.', in Looking at It from Asia: The Processes That Shaped the Sources of History of Science, ed. by Florence Bretelle-Establet (Dordrecht: Springer, 2010), pp. 37-80.
} 
and suan. That leaves us on the question of the representativeness of our sample, but, returning to third-century $l i$, we shall hear experts voicing all-too-similar concerns about the reliability of the written word.

\section{Towards the Oral Culture of Textual Astronomy}

In the last two decades, early China studies has witnessed a surge of interest in the role of orality and memory in the production, reproduction, storage, and transmission of the texts that have come down to us in written form. ${ }^{39}$ This movement has been generally limited to a handful of genres at sinology's traditional core: pre-Shiji 史記 (c. $90 \mathrm{CE}$ ) poetry, classics, philosophy, and histories. It has been limited, more importantly, by how little these sources actually say about non-written transmission, leaving scholars to assume models from elsewhere or try teasing evidence of dictation and memory from textual variants. ${ }^{40}$ The problem is that variora like 志 *tśa ('ambition') vs 詩*'ś ('odes') in philosophy, for example, leave a whole lot more room for interpretation than a 八 * pet ('eight') vs 六*liuk ('six') in mathematical astronomy. ${ }^{41}$ As such, it seems wise to throw mathematical astronomy at the problem, even (and especially) if $l i$ is the indoors, text-based side of the astral sciences. ${ }^{42}$

The practice of $l i$ relies on data, but, as we have already seen, data as written down and copied in this manuscript culture might not be reliable as such. How bad is it? As to your basic coordinate system,

\footnotetext{
${ }^{39}$ See for example Martin Kern, 'Methodological Reflections on the Analysis of Textual Variants and the Modes of Manuscript Production in Early China', Journal of East Asian Archaeology, 4.1-4 (2002), 143-81; Martin Kern, 'The Odes in Excavated Manuscripts', in Text and Ritual in Early China, ed. by Martin Kern (Seattle: University of Washington Press, 2005), pp. 149-93; David Schaberg, A Patterned Past: Form and Thought in Early Chinese Historiography (Cambridge: Harvard University Asia Center, 2001), pp. 315-324; Dirk Meyer, Philosophy on Bamboo: Text and the Production of Meaning in Early China (Leiden: Brill, 2012), passim.

${ }^{40}$ The work of classicists has provided considerable inspiration in this regard, e.g. Eric Havelock, Preface to Plato (Cambridge, Mass.: Harvard University Press, 1963) and Rosalind Thomas, Literacy and Orality in Ancient Greece (Cambridge: Cambridge University Press, 1992).

${ }^{41}$ On the example of 'ambition' vs 'odes', see Matthias L Richter, The Embodied Text Establishing Textual Identity in Early Chinese Manuscripts (Leiden: Brill, 2013), pp. 127-87. The only truly unequivocal clues about textual (re)production that we can hope to discover from manuscripts themselves, as written objects, are probably those pointing to direct visual copying - visual confusion, visual reproduction, etc.- - as I have argued in 'A Positive Case for the Visuality of Text in Warring States Manuscript Culture', presented at The Rise of Writing (University of Chicago, 15-16 October 2011) and hope soon to publish.

${ }^{42}$ On the outdoor/indoor, observation/text divide between tianwen 'heavenly patterns' and $l i$ 'sequencing', see Morgan, Astral Sciences in Early Imperial China, ch. 2.
} 
the equatorial widths of the twenty-eight zodiacal lodges as found in daybook B from Fangmatan 放馬灘 tomb 1 (sealed 3rd cent. BCE) and on the lacquer dial from Shuanggudui 雙古堆 tomb 1 (sealed $165 \mathrm{BCE}$ ) exhibit considerable differences with both one another and received sources. ${ }^{43}$ As to your basic chronology, not only were many of the grand celestial phenomena/omens in the standard histories fabricated, as Huang Yi-long 黃一農 has shown, but experts were (sardonically) aware of this. ${ }^{4}$ Importantly, as Han Yi reminds us in 226, we are dealing with a world where one runs the risk of staking one's reputation on an out-of-date edition of the competitor's work.

The lesson here is that texts can be more hindrance than help unless you already know what you are doing. In general, the greater the expert, the greater his vehemence against the value of the written word, even as he himself is writing texts. Take for example Wang Fan's (written) criticism of Lu Ji's 陸績 (188-219) cosmology:

至以日景驗之, 違錯甚多, 然其流行, 布在衆書, 通儒達士, 未之考正, 是以不敢背損舊術, 猶摅所見。

Si l'un soumet (la théorie adoptée par Lu Ji) à l'épreuve des ombres du Soleil, on s'aperçoit que la valeur du rayon céleste est beaucoup trop grande. Or, du fait que cette théorie est très répandue et reproduite dans une multitude d'écrits, les lettrés moyens et ordinaires n'ont pas cherché à en vérifier (l'exactitude). Aussi n'ont-ils jamais osé s'opposer par la critique aux anciens procédés et se sont contentés de suivre ce qui leur était proposé (dans ces ouvrages). ${ }^{45}$

How was one to go about mastering $l i$ if not by the 'multitude d'écrits'? For functionaries, we know the astronomical office to have begun providing on-the-job training sometime around the Sui 隋 (581-618), when it added erudites (boshi 博士) and trainees (sheng 生) in li, tianwen, clepsydrae, and omenology to its staff. ${ }^{46}$ Before this, however, we must turn to the individual cases of elites suffi-

\footnotetext{
${ }^{43}$ See Pan Nai 潘腯, Zhongguo hengxing guance shi 中國恆星觀測史, $2 \mathrm{~d}$ ed. (Shanghai: Xuelin chubanshe, 2009), pp. 29-41; Sun Zhanyu 孫占宇, 'Fangmatan Qin jian rishu “Xing du” pian chutan’ 放馬灘秦簡日書「星度」篇研究, Kaogu 考古, 2011.4, 70-79.

${ }^{44}$ Shehui tianwenxue shi shi jiang 社會天文學史十講 (Shanghai: Fudan daxue chubanshe, 2004), pp. 1-71.

${ }^{45}$ Huntian xiang shuo, cited in Kaiyuan zhanjing, pp. 1.15a-b; tr. Marc Kalinowski, 'Le calcul du rayon céleste dans la cosmographie chinoise', Revue d'histoire des sciences, 43. 1 (1990), 3-34 (p. 13). For another example of experts' criticism of amateurs' blind reliance on book learning, see Cai Yong's 蔡坙 (133192) debate speech of 175 in Cullen, 'Actors, Networks, and "Disturbing Spectacles” in Institutional Science', pp. 253-264.

${ }^{46}$ See Sui shu, p. 28.775; Tang liu dian 唐六典 (Siku quanshu ed.), pp. 10.13a16a (commentary); cf. Chen Xiaozhong 陳曉中 and Zhang Shuli 張淑莉, Zhongguo gudai tianwen jigou yu tianwen jiaoyu 中國古代天文機構與天文教育 (Beijing: Zhongguo kexue jishu chubanshe, 2008), pp. 297-304.
} 
ciently famous to attract the attention of imperial historiographers to look for patterns.

Of the astral and mathematical sciences, we know omens, prophecy, and mathematics to have been integral elements of the officeholding elite's education in this period. ${ }^{47} \mathrm{Li}$ mathematical astronomy, by contrast, was somewhat 'extracurricular'. Some, like Sima Qian 司馬遷 (c. 145 - c. 86 BCE), Liu Xin 劉歆 (c. 50 BCE - 23 CE), Zheng Zhong 鄭眾 (d. 83), and the brothers Zong Cheng 宗誠 and Zheng 整 (fl. 174-180) belonged to family traditions. ${ }^{48} \mathrm{Li}$ was also taught in schools. Zhang Heng 張衡 (78-139) and Zheng Xuan 鄭玄 (126-200) learned it at the Imperial Academy, and it was from Liu Xin's private lectures that Zheng Zhong's father Xing 興 (fl. 14-33) had learned it - the latter a model of private education that we know in the provinces to have attracted hundreds of pupils to the subject. ${ }^{49}$ There were also those who learned from social inferiors, suggesting relationships of private tutorial. Empress Deng Sui 鄧綏 (81-121), for example, learned the astral sciences from literata Ban Zhao 班昭 (44/49118/121), and Sima Qian learned his star lore from the wonderworker Tang Du 唐都 (fl. 104 BCE). ${ }^{50}$

\footnotetext{
${ }^{47}$ On the place of omen and prophecy literature, see Jack L. Dull, 'A Historical Introduction to the Apocryphal (Ch'an-Wei) Texts of the Han Dynasty' (Ph.D. diss., University of Washington, 1966); Lü Zongli 呂宗力, Power of the Words: Chen Prophecy in Chinese Politics, AD 265-618 (Oxford: Peter Lang, 2003). On suan mathematics, see Christopher Cullen, 'People and Numbers in Early Imperial China: Locating "mathematics" and "mathematicians" in Chinese Space', in Oxford Handbook of the History of Mathematics, ed. by Eleanor Robson and Jacqueline A. Stedall (Oxford: Oxford University Press, 2009), pp. 591-618.

${ }^{48}$ Both Sima Qian and Liu Xin's fathers were famously involved with the astral sciences, Qian inheriting the directorship of the astronomical office from his. As the son of Zheng Xing, Zheng Zhong 'received the Zuo Tradition of the Spring \& Autumn Annals from his father, was vigorous in his studies, and understood the Triple Concordance $l i$ 從父受左氏春秋，精力於學，明三統歷 that his father had learned, in turn, from Liu Xin (Hou Han shu 後漢書 [Zhonghua shuju ed.], p. 36.1224). Brothers Zong Cheng and Zheng appear at court in 174-180 as experts on eclipse prediction like their grandfather, Zong Gan 宗紺 (fl. 89-90) before them (Hou Han shu, zhi 2, pp. 3040-41).

${ }^{49}$ For Zhang Heng, see Hou Han shu, p. 59.1897. For Zheng Xuan, see Hou Han shu, p. 35.1207. Zheng Xing, we are told, 'followed Liu Xin as a disciple for his lectures on the correct and great meaning (of the classics); Xin praised Xing's talents, making him compose "regulation" and "sentence \& verse" commentarial exegesis as well as collate the Triple Concordance $l i$ ” 將門人從劉歆講正大義, 歆 美興才，使撰條例、章句、傳詁，及校三統歷 (Hou Han shu, p. 36.1217). As to provincial schools, the wonder-workers Liao Fu 廖扶 and Fan Ying 㚞英 associated, among other things, with tianwen and xing suan 星算 ('star calculation'), were known to have taught such large numbers of disciples (Hou Han shu, pp. 82A.2719-21). It is in this sort of environment, for example, that Yang Tong 楊 統 (fl. 76) is said to have learned 'the techniques of tianwen and [astronomical] calculation' 天文推步之術 from a 'Zheng Boshan of his same commandery' 同郡 鄭伯山 in Xindu 新都, near Chengdu (Hou Han shu, p. 30A.1074).

${ }^{50}$ The daughter of a family of influential figures, Ban Zhao was sought out in 108 by Empress Deng to teach her 'the classics as well as tianwen and mathematics' 經書, 兼天文、等數 (Hou Han shu, p. 10A.424). Tang Du was one of the outside
} 
What did li education look like? It is difficult to say: our sources simply note the 'transmission' (chuan 傳) and 'reception' (shou 受) of 'methods' ( $f a$ ), 'techniques' (shu), 'models' (shi 式), and li from one person/institution to another. Since the vocabulary is the same, one imagines that this would have worked as per the standard curriculum, which focused on writing and, then, the reading, recitation, and memorization of classics. Primary education began at home, the student typically taking a master at around the age of eight. In the case of private schools, masters tended to take more students than they could personally instruct and thus relied upon a tiered system whereby a manageable core of personal disciples were responsible for educating the outer rungs. Masters, however, would also hold 'lectures' (jiang 講) to explain and take questions on a given textlectures open to scholars beyond the walls of their school. We know considerably less about home schooling, tutorial, and personal exchange (below), but we can assume that this was equally oral and face to face. ${ }^{51}$ Returning to the astral sciences, Li Chunfeng for one reports committing twenty-five tianwen titles to memory in his youth through 'practice and recitation' 習誦, ${ }^{52}$ but of all we hear about its sister science of $l i$ one rather interesting pattern stands out: practitioners boast of 'receiving' a 'master's method' but never of having begun one's studies through independent reading.

Assistant Director Han Yi, to return to the events of 226, was clearly a man who knew his craft. He began with the realization that 'the Supernal Icon went too far in reducing [its value for the solar year] and that in time it would slip ahead of heaven' 乾象減斗分太 過後當先天, about which he was absolutely right. ${ }^{53}$ His solution sur-

experts called in to participate in the famous $l i$ reform of 104 BCE, his responsibility being $l i$ numbers, stars, and the divisions of heaven (Shiji 史記 [Zhonghua shuju ed.], pp. 26.1260, 27.1349, 112.2965. For his role educating Sima Qian, see Shiji, p. 130.3288 .

${ }^{51}$ What little we know about education in China's early imperial period is surveyed in Thomas H. C. Lee, Education in Traditional China: A History (Leiden: Brill, 2000). On private education, see also Yu Shulin 余書鱗, 'Liang Han sixue yanjiu’ 兩漢私學研究, Shida xuebao 師大學報, 11 (1966), 109-48.

${ }^{52}$ Yisi zhan 乙巳占 (Shiwan juan lou congshu 十萬卷樓叢書 ed.), p. 1.11a.

${ }^{53}$ Song shu, p. 12.231; Jin shu, p. 17.498. Our sources frame the problem in terms of 'Dipper parts' (Dou fen 斗分), which is to say the numerator of the fractional part of a $d u$ at the tail-or rather Dipper. ${ }_{\text {L08 }}$ ( $\mu-\zeta$ Sgr) - end of one circuit of heaven. Liu Hong 'reduced' his predecessors' 3651/4 du circuit to $365145 / 589$ or $\approx 365.2462 d u$, which, as explained in Note 23 , is the same value as the length of the solar year as measured in days. The length of the solar year as measured in days, furthermore, is linked to the synodic month by the 'rule' (zhang 章) of 19 years : 235 lunations. The problem is what will happen 'in time', and matters of testing refer to the moon, which is faster and easier to measure than the sun, so let us consider 'Dipper parts' in terms of its impact on the lunation. Liu Hong's value for the solar year results in a synodic month of $29773 / 1457$ or $\approx 29.530542$ days, which falls 3.7 seconds short of its value at epoch (29.530585 days). This would indeed 'slip ahead' (rather than behind), and Han Yi adjusts this to $296409 / 12079$ or $\approx 29$. 530599 days, 1.2 seconds greater than its true value. 
vived a multi-year trial at the astronomical bureau, and the results were good enough that the director recommend it to the throne, that the throne entrusted it to its high ministers, and that the ministers disagreed to the point of necessitating a public debate. At that debate, furthermore, confronted with Xu Yue's eclipse data, Han Yi only loses to the Supernal Icon $l i$ as we know it (without xiaoxi) two to three by a margin of ten minutes. ${ }^{54}$ All of this speaks pretty highly to his training; the problem, however, is what he found himself facing off against on the day of the debate was not the Supernal Icon $l i$ as we know it, nor the Supernal Icon $l i$ as he knew it, but a third, more 'astonishing' Supernal Icon $l i$ 'with xiaoxi' known only by Xu Yue.

Where did all of these Supernal Icon $l i$ come from? What we know of the text's 'reception' paints a rather complex picture of multiple transmission and international diffusion. Xu Gan 徐幹 (170-218) describes Liu Hong as having 'constructed' (zao 造) and memorialized the Supernal Icon $l i$ late in the reign of Emperor Ling 靈帝 (r. 168-189), while he was stationed in Kuaiji 會稽 as commandant of its Eastern Regiment. ${ }^{55}$ Just prior to the emperor's death and the ensuing coup d'Etat in 189, Yuan Shansong 袁山松 (d. 401) adds, '[Liu Hong] was recalled (to Luoyang), but before arriving, he was appointed the governor of Shanyang' 徵還, 未至, 領山陽太守. ${ }^{56} \mathrm{It}$ was there, or roundabouts, that Liu met Zheng Xuan:

獻帝建安元年, 鄭玄受其法, 以為窮幽極微, 又加注釋焉。

Emperor Xian 獻帝 (r. 189-220) Jian'an 建安 year 1 (196), Zheng

Xuan received his method $(f a)$, and considering it to plumb all that is

recondite and crown all that is subtle, he further added commentary

\& explanation to it. ${ }^{57}$

196 happens to be the year that we know Zheng Xuan to have been sojourning in Xuzhou 徐州, two or three days' ride $(120 \mathrm{~km})$ from Shanyang - a coincidence from which Chen Meidong 陳美東 infers face-to-face 'reception'. ${ }^{58}$ Three things are rather curious about this exchange. First, as mentioned above, is that it comes at least ten years prior to our version of the Supernal Icon li. Second, neither figure was the other's clear social superior, so this looks like a case of learning by friendly exchange. Zheng was a well-established textual scholar and educator who, after fourteen years' imprisonment a decade earlier, avoided politics at all cost; Liu, on the other hand, was a

\footnotetext{
${ }^{54}$ Jin shu, p. 17.500. For more on the eclipse data presented at the 226 debate, see Qu Anjing 曲安京, 'Zhongguo gudai lifa zhong de jishi zhidu' 中國古代曆法 中的計時制度, Hanxue yanjiu 漢學研究, 12.2 (1994), 157-72; Morgan, Astral Sciences in Early Imperial China, ch. 5.

${ }_{55}^{5}$ Zhong lun 中論 (Siku quanshu 四庫全書 ed.), p. B.13a.

${ }^{56}$ Yuan Shansong shu 袁山松書, cited in Hou Han shu, zhi 2, p. 3043 commentary.

57 Jin shu, p. 17.498.

58 'Liu Hong', p. 132.
} 


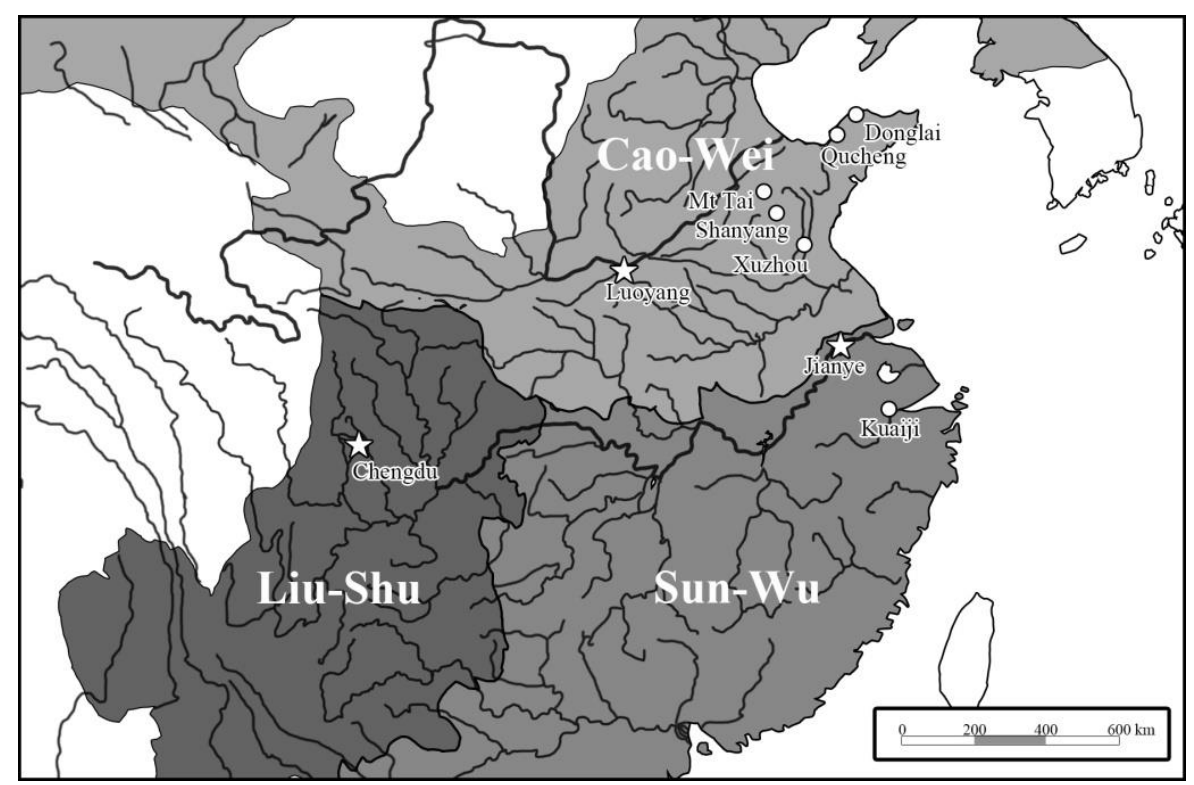


successful military and civil officer of noble birth whose intellectual output was rather focused on mathematical astronomy. Zheng had expressed an interest in maths and astronomy since his youth; Liu, sharing this passion, was probably delighted to share his work. ${ }^{59}$ Lastly, what is curious about this exchange is the point at which commentary-writing occurs: it occurs after 'reception' viva voce as a sort of final stage in the learning process. Sadly, Zheng Xuan's 'commentary \& explanation' is lost and appears nowhere in later bibliographies.

$\mathrm{Xu}$ Yue refers to Liu Hong as his 'master', claiming elsewhere to have sought out 'Liu Kuaiji' 劉會稽 (i.e. Hong) at the latter's ancestral home near Mt Tai 泰山. ${ }^{61}$ According again to Yuan Shansong, Liu Hong had left Mt Tai by 167, returning only circa 174/178 to mourn his father. ${ }^{62}$ Given that Xu Yue calls Liu 'Kuaiji', after his southern military command circa 178/189, they must have met at Mt Tai after 189, when Liu was posted to Shanyang and Qucheng 曲 城. Qucheng is a mere $70 \mathrm{~km}$ from Xu Yue's home in Donglai 東萊, making one wonder why they would have met at Mt Tai, but the story gets stranger as we move into the Three Kingdoms (220-280):

其劉氏在蜀, 仍漢四分曆。吳中書令闒澤受劉洪乾象法於東萊 徐岳, 又加解注。中常侍王蕃以洪術精妙, 用推渾天之理, 以 制儀象及論, 故孫氏用乾象曆, 至吳亡。

The House of Liu 劉 were in [the state of] Shu 蜀, which kept the Han Quarter-remainder li (Sifen li 四分曆). Prefect of the Palace Writers for the State of $\mathrm{Wu}$ Kan Ze 闒澤 (d. 243) received Liu Hong's Supernal Icon method ( $\mathrm{fa}$ ) from Xu Yue of Donglai and added exegesis \& commentary to it. Regular Palace Attendant Wang Fan considered [Liu] Hong's procedures $(s h u)$ marvellous, and he used them to extrapolate the principles of sphere heaven [cosmology] to formulate an instrument (armillary sphere) and discourse. Thus it was that the House of Sun 孫 used the Supernal Icon $l i$ until the demise of $\mathrm{Wu}^{63}$

\footnotetext{
${ }^{59}$ On Zheng Xuan's engagement with mathematics, see Cullen, 'People and Numbers', p. 606. Our impression that, outside the hierarchically-structured contexts of family, school, or tutelage, technical knowledge may also have been passed between peers is likewise suggested by the case of Zhai Fangjin 翟方進 (d. 7 BCE). A self-made man of humble origins who had risen to the rank of chancellor, Zhai is said to have taught the Zuo Tradition to Liu Xin (an influential statesman and intellectual of noble birth), his mastery of which would inform the core of the latter's later astronomical endeavours. He also taught 'stellar/planetary $l i$ ' 星曆 to Tian Zhongshu 田終術, the mayor of the capital (Han shu 漢書 [Zhonghua shuju ed.], pp. 36.1967, 84.3421).

${ }^{60}$ The only potential candidate one sees in later bibliographies is the five-juan edition by 'Liu Hong, et al.' in the Liang imperial catalogue; see Note 10.

${ }^{61}$ Shushu jiyi 數術記遺 (Siku quanshu ed.), 1 b.

${ }^{62}$ Yuan Shansong shu, cited in Hou Han shu, zhi 2, p. 3043.

${ }^{63}$ Song shu, p. 12.259; Jin shu, p. 17.503.
} 
Whatever the status of the Supernal Icon $l i$ he 'received'-be it before or after Zheng Xuan-Xu was apparently the vector for its transmission south, Kan Ze and Wang Fan being members of the rival Sun-Wu court. As far as transmission vectors go, this one is oddly tortuous. First, it is unclear how Xu Yue and Kan Ze would have met. $\mathrm{Xu}$ was a northerner who appears at the Cao-Wei court with no known official duties that might take him elsewhere; Kan, on the other hand, was a man of humble origins in Kuaiji whose career took him little further than the Sun-Wu court in Jianye 建業. Second, if Kan 'received' the Supernal Icon $l i$ whilst prefect of the palace writers, to which he was appointed $232 / 238,{ }^{64}$ it would place this transmission a decade after the adoption of a Supernal Icon $l i$ there in 222. There must obviously have been something special about Xu's version that merited 're-reception' across hostile borders. Third, and most strange of all, is that it was while serving in Kan's hometown in the 180s that Liu Hong actually finished a/the Supernal Icon $l i$, so it had travelled quite a ways just to get back to a man from Kuaiji through Xu Yue's hands some five decades later.

The Liu-Shu court kept the failing Quarter-remainder $l i$ of $85 \mathrm{CE}$ that they had inherited from Han, from whom it claimed its royal ancestry. One suspects it did this out of reverence rather than ignorance, however, as there is evidence that the Supernal Icon $l i$ made it there as well. During the reign of Sun Xiu 孫休 (r. 258-264), for example, we know Supernal Icon enthusiast Wang Fan to have been dispatched there as an emissary to the Liu-Shu court, where it is said that he made a considerable impression for his erudition. ${ }^{65}$

This, unfortunately, is all that may be gleaned from our sources, and it leaves us with far more questions than it does answers. What came of the Supernal Icon $l i$ in the Kingdom of Shu? How did $\mathrm{Xu}$ Yue and Kan Ze meet? What was Liu Hong's contemporary impact in Kuaiji, and why was his work reintroduced to the region from the North? Who, indeed, is this Xu Yue? Why was the Cao-Wei astronomical office so out of the loop? What is xiaoxi? How many Supernal Icon $l i$ were in circulation? And where does our one-fascicle Book of Jin version fit into all of this? All of the confusion that that these sources stirs up reveals something precious about the complexity of the network of practice and textual transmission behind the policy reforms of third-century $l i-$ a complexity far beyond the old narrative of the subject's 'secret' and 'official character'. ${ }^{66}$ What we can say is this: the Supernal Icon $l i$ crystalized in written form after 'more

\footnotetext{
${ }^{64}$ For Kan Ze's biography, see Sanguo zhi, pp. 53.1249-50.

${ }^{65}$ For Wang Fan's biography, see Sanguo zhi, pp. 65.1453-54.

${ }^{66}$ For example, Joseph Needham, Science and Civilisation in China, vol.3: Mathematics and the Sciences of the Heavens and the Earth (Cambridge: Cambridge University Press, 1959), pp. 186-94; Nakayama Shigeru 中山茂, 'Characteristics of Chinese Calendrical Science', Japanese Studies in the History of Science, 4 (1965), 124-31; Nathan Sivin, 'Cosmos and Computation in Early Chinese Mathematical Astronomy', T’oung Pao, 2d ser., 55.1/3 (1969), 1-73.
} 
than twenty years' of 'contemplation', and it continued to evolve at the hands of its creator, commentators, and users for at least that long thereafter as, decade after decade, 'methods', 'techniques', 'models', and $l i$ were 'received' from the source, written down, commented upon, and transmitted along lines of personal exchange.

\section{Conclusion}

Staring into the confusion posed by the Supernal Icon li's transmission history and the sort of corruption that one sees in early imperial manuscripts in technical fields, one begins to understand why it mattered so much to our historical subjects to have a 'master's method' 'received' in person. It mattered in terms of the way they went about learning the subject, but it mattered also in terms of establishing one's credibility as an authority. Assistant Director Han Yi lost the debate in 226, but more than that, as spelled out in Yang Wei's 楊偉 (fl. 226-237) concluding remarks, he lost his credibility:

\section{今韓翊據劉洪術者, 知貴其術, 珍其法。而棄其論, 背其術, 廢其言, 違其事, 是非必使洪奇妙之式不傳來世。若知而違之, 是挾故而背師也; 若不知而據之, 是為挾不知而罔知也。 \\ Now, from Han Yi's reliance on Liu Hong's procedures [we see that he] knows to esteem his procedures and treasure his methods, and yet he dismisses his discourse, forsakes his procedures, abandons his words, and strays from his endeavour, the inevitable result of which will be to stop Hong's unique \& marvellous model (shi) from being transmitted to future ages. If he is straying from it knowingly, then he has intentionally forsake [the] master; if he is basing himself upon it unknowingly, then he has ignorantly arrived at a confused under- standing. ${ }^{67}$}

The picture that emerges from a granular analysis of this period is considerably more mixed than our old idea of the astral sciences as the exclusive domain of hereditary practitioners secreted in a tightlycontrolled government laboratory. Instead, we see a field composed of eclectic characters connected by an elaborate network of personal, professional, educational, and family ties extending unfettered across institutional, geographic, and even war-torn political divides. ${ }^{68} \mathrm{Peo}-$ ple circulated texts, and as they did, the texts evolved, and so too did

${ }^{67}$ Jin shu, p. 17.503 .

${ }^{68}$ For recent work to correct earlier ideas about the sociology of early imperial $l i$ in terms of 'mixity', see in particular Cullen, 'Actors, Networks, And "disturbing Spectacles" in Institutional Science'; Chen Meidong 陳美東, Zhongguo gudai tianwenxue sixiang 中國古代天文學思想 (Beijing: Zhongguo kexue jishu chubanshe, 2007), esp. pp. 17-32; Nathan Sivin, Granting the Seasons: The Chinese Astronomical Reform of 1280, with a Study of Its Many Dimensions and a Translation of Its Records (New York: Springer, 2009), pp. 58-59, 151-70. 
the knowledge systems from which they sprang (and of which they were but snapshots in time). 'The Supernal Icon li-which Supernal Icon $l i$ ?' we should ask ourselves, taking comfort in the fact that our historical subjects were as confused by their texts as are we. Faced with confusion, then, as in our own day, experts evaluated one another's credibility based just as much on the criteria of experience, association, and the date and reputation of the oral instruction received.

This, more than anything else, is why Han Yi lost the debate. Xu Yue's word trumped several years of trials and research, because $\mathrm{Xu}$ Yue's word went back to the late master and a fateful trip decades ago to the sacred mountain where he was born. The only problem, of course, is that $\mathrm{Xu}$ Yue's 'predictions' are retrospective, his defence of his master is personal, no one's heard of his 'astonishing' xiaoxi, nor, eleven years later, does it make it into Yang Wei's own $l i{ }^{69}$ The written word may have had its problems for early imperial astronomy, one might say, but so too did the spoken word alone.

\footnotetext{
${ }^{69}$ Yang Wei’s Luminous Inception li (Jingchu li 景初曆) is preserved in Song shu, pp. 12.232-64, and Jin shu, pp. 18.535-62. Xiaoxi appears neither here nor in any subsequent $l i$ in the Supernal Icon $l i$ tradition; see Note 5.
} 